\title{
Financial Stability and the Insurance Sector*
}

\author{
Jean-Claude Trichet \\ Governor, European Central Bank, Kaiserstrasse 29, D-60066 Frankfurt am Main, Germany. \\ E-mail: gilles.noblet@ecb.int
}

This paper focuses on the relevance of the insurance sector for the overall stability of the financial system by outlining the sources of risk and vulnerability facing the industry. The growing interlinkage between insurers and banks is analysed. The paper concludes by identifying some key challenges for the insurance sector.

The Geneva Papers (2005) 30, 65-71. doi:10.1057/palgrave.gpp.2510021

Keywords: financial stability; insurance and banking; European Central Bank

Financial systems are becoming ever more complex. Whereas in the past financial stability was mainly associated with banking sector conditions, nowadays the important roles played by other intermediaries such as insurance companies have to be taken fully into account. This article focuses on the relevance of the insurance sector for the overall stability of the financial system. The first section begins by outlining, in general, how situations of financial stability can be characterized and the role that central banks can play in safeguarding it. Next the specific role of the European Central Bank (ECB) and the European System of Central Banks (ESCB) in financial stability is discussed. Then the sources of risk and vulnerability facing the banking and insurance sectors are briefly discussed and some implications for financial stability are derived. After a review of recent developments in the European insurance sector, the links that have been developing over time between the insurance and banking sectors are considered. The next section goes on to look at the responses of the authorities to these interlinkages. Finally, I conclude by identifying some forthcoming key challenges for the insurance sector.

\section{Financial stability and the role of central banks}

Financial stability is a somewhat elusive concept as is demonstrated by the absence of a widely recognized definition. While it is evident when a financial system is unstable or in a crisis situation, it is much more difficult to assess in normal circumstances whether or not the system is moving towards instability. The definition underpinning financial stability work at the ECB sees it as a condition where the financial system can withstand shocks without giving way to processes that impair the allocation of savings to investments and the processing of payments in the economy. ${ }^{1}$

\footnotetext{
* This article is a reworked version of the speech that Mr Trichet delivered as a guest speaker at the 31st General Assembly of the International Association for the Study of Insurance Economics that took place in Madrid from 26 to 29 May 2004.

${ }^{1}$ Padoa-Schioppa (2003).
} 
This definition emphasizes that in a situation of instability, the financial system is unable to perform its basic task of providing the financing needed to support real economic processes. It also stresses that to safeguard financial stability, the system should be resilient to potential shocks. Finally, it recognizes that the health of each sub-component of the financial system can be important in determining its overall stability. Whereas banks continue to play a special role in the financial system, other elements such as conditions in financial markets, which allow banks to price and hedge risks and are playing an increasing role in the financing of economic processes, and the financial health of non-bank financial institutions (in particular, insurance companies) can also affect the system's robustness. Therefore, the different constituent parts of the financial system and their interlinkages play an increasingly important role for the stability of the financial system.

Central banks have a natural role to play in ensuring financial stability and have a strong interest in fostering it for several reasons. A stable financial system, sufficiently robust to allocate financial resources in the economy efficiently, is a precondition for successful monetary policy transmission. Central banks also have an interest in having sound counterparties for their monetary policy operations, calling for the monitoring of their financial condition. Furthermore, as issuers of legal tender, central banks can provide immediate and ultimate liquidity to the financial system, which is crucial in times of crisis. Finally, central banks are responsible for the smooth functioning of payment systems, disturbances in which can propagate financial crises.

\section{The role of the ECB/ESCB}

As to the specific role of the ECB and the ESCB in financial stability, by contrast with the objective of price stability, the statutory texts do not entrust them with a primary competence in the field of financial stability. Nevertheless, the ECB and the ESCB have been allocated specific tasks. The ESCB must promote the smooth operation of payment systems, which play a significant role in achieving financial stability. The ESCB also has a duty to contribute to the smooth conduct of policies pursued by the competent authorities relating to financial stability. This latter responsibility should be seen against the backdrop of the introduction of the euro, which has changed the nature of systemic risk. Markets have become more integrated and intermediaries more interlinked. This has improved the system's ability to absorb shocks, but at the same time increased the scope for contagion. More attention has therefore to be paid to euro area-wide developments concerning financial stability.

One of the main elements of the ESCB's tasks in the area of financial stability is a regular monitoring of financial stability conditions in the euro area. This monitoring is conducted in collaboration with the Banking Supervision Committee (BSC), an ESCB Committee that consists of high-level representatives from European Union (EU) central banks and banking supervisory authorities and the ECB. The BSC's purpose is to identify potential sources of vulnerability and to assess the system's resilience to potential shocks. While it is the financial system at large that is being monitored, the focus continues to be on banks as they still represent the main component of the European financial system. The outcome of the monitoring activity supports 
discussions within the ECB's decision-making bodies and also feeds into international discussions, such as those of the Financial Stability Forum, the Economic and Financial Committee and other international informal groupings of major importance, such as the G7, G10 and G20.

A second major task in this area is policy input given by the ECB to the development of financial regulation and supervision, which are also important elements to safeguard financial stability. The input can take different forms, including formal opinions on draft legislative proposals at the national or EU level, policy stances in international discussions and replies to public consultations. In this context, it should be mentioned that the ECB is present in different capacities in the relevant international and European forums dealing with financial stability and supervision.

A third major task is the promotion of cooperation between central banks and banking supervisory authorities on issues of common interest. This activity, which is also pursued through the BSC, tends to focus on specific central banking activities (such as payment systems oversight and the management of credit registers) and arrangements for crisis management.

\section{Banking and insurance: different businesses, different financial stability concerns}

Banking and insurance are two different businesses, which pose different financial stability concerns. Banks continue to play a special role in the financial system, which derives from their central role in the transmission of monetary policy, the payment system and the reallocation of savings to investments. Moreover, because their assets are long-term and their liabilities are short-term and repayable at par on a "first-come, first-served" basis, banks are vulnerable to depositor runs. Through the close interconnections between banks in the interbank market and payment systems, problems can quickly be transmitted from one institution to another. In short, problems in the banking sector have the potential to create systemic risk.

The insurance sector is also of considerable importance to the economy. It acts as a conduit for households and firms to transfer risks to entities that are better suited to handle them. In this way, projects are undertaken that might otherwise not be, and this contributes to economic growth. Just like banks, insurance companies mobilize savings from households and firms and invest part of them in non-financial sectors of the economy. A key difference with the banking sector, however, lies in the balance sheet structure. In general, the average maturity of insurance companies' liabilities is longer than that of their assets, which makes them much less vulnerable to customer runs. In addition, insurers are not as strongly interconnected through the interbank market and payment systems as banks are. They do not directly participate in payment systems, nor are they a prime transmission channel for monetary policy.

Traditionally, insurance companies have been regarded as posing potentially lower systemic risks than the banking sector. This view is reflected in the fact that prudential rules for insurance companies are generally less extensive compared with those that apply to banks. However, this traditional approach does not take into account the growing interaction between the insurance sector, financial markets (such as those for bonds, stocks and derivatives) and other financial intermediaries. From a financial stability perspective, this interaction now plays a very important role. 


\section{Recent financial stability conditions in the insurance sector}

Before elaborating further on this, it is useful to review the recent financial performance of the European insurance sector. Over recent years, the sector has faced many challenges. Some European insurers suffered losses for several years in succession. On the basis of a sample of large European insurers analysed at the ECB, financial statements for 2003 show substantial signs of improvement.

Many of the challenges faced by the sector over recent years can be traced to the decline in equity markets that began in 2000 and the subsequent downward pressure on long-term interest rates. Before the stock market correction, several European insurers had increased their share portfolio, lured by the prospect of high returns in an environment of low interest rates. These increased exposures made them vulnerable to the subsequent stock market decline. Downward pressure on long-term interest rates worsened matters as the net present value of future liabilities rose. This was particularly an issue for those companies that had to service long-term contracts with high guaranteed returns. Finally, non-life insurers were confronted with significant increases in claims due to terrorist attacks, corporate defaults and natural catastrophes.

However, several positive developments have emerged as the insurance sector has responded to the challenges. Stock market exposures are gradually being reduced in favour of bonds, which is helping to reduce balance sheet mismatches. The more favourable trends in stock and corporate bond markets observed last year and early 2004 have eased balance sheet strains. Profitability has stopped deteriorating in many instances, and a number of insurers have improved their solvency through new equity issuance. Market indicators, such as expected default frequencies and spreads on subordinated debt, also strongly suggest that the shock-absorbing capacity of the sector has improved. The outlook of the insurance sector, however, continues to depend to a large extent on developments in financial markets.

\section{Interlinkages between the banking and insurance sectors}

From a central bank's perspective, the identification of the linkages between the banking sector and the insurance sector is of particular interest because these determine the channels through which the insurance sector's problems might spill over to banks. Such contagion channels can either be direct or indirect.

Direct links exist through credit exposures and ownership links. According to information collected by the BSC in 2001 and 2002, it seemed that the direct credit exposures of the banking sector to the insurance sector were, all in all, limited. At that time, some concerns were also raised regarding the market for credit risk transfer (CRT) instruments, such as credit derivatives. To shed light on this issue, the BSC conducted a survey of EU banks' activities in CRT markets, the findings of which were recently published. ${ }^{2}$ Whereas the survey takes the banks' perspective, it also contains relevant information for insurance companies. The report finds that, while banks were

\footnotetext{
${ }^{2}$ ECB (2004).
} 
especially active as protection buyers, insurers often acted as protection sellers in an attempt to enhance profitability. According to a FitchRatings report of September 2003, the global insurance industry had a net protection-selling position of U.S.\$303 billion in credit derivatives. Excluding so-called mono-line insurers, net investments of the industry in these products amounted to U.S.\$137 billion. ${ }^{3}$ The concerns mentioned earlier related especially to the transparency of the market and the exposures assumed by insurers that were financially vulnerable. But it seems that towards the end of 2003, insurers became less active in the market, which might have been a reaction to a number of corporate defaults.

Another way in which significant links can exist between banks and insurance companies is through financial conglomerates. The major bancassurance groups play an important financial role in the EU, with large market shares in both the banking and insurance markets. It seems that such groups are mainly active in banking, which illustrates that bancassurance is often a trend instigated by banks attracted by crossselling opportunities. The diversified nature of such groups might raise revenues and lead to lower overall risk at the group level, while also posing new challenges. ${ }^{4}$ Conglomerates in addition pose certain questions that have been well documented by the Joint Forum, ${ }^{5}$ such as the multiple use of the same capital by different group entities and regulatory arbitrage.

The indirect links between the two sectors are perhaps less straightforward to identify, but can nevertheless be significant. One source of indirect links derives from the participation of insurance companies in financial markets. Insurance companies might be forced to sell assets in an already downward-orientated market as a result of pressure from supervisors or rating agencies. This can lead to further price declines that may spill over into banks' securities portfolios. Another indirect link might result from the growing importance of hybrid financial products, such as life insurance policies with a minimum guaranteed return or unit-linked life policies. Such products compete with more traditional banking products, in particular long-term deposits and shares in investment funds.

\section{Responses by authorities to increasing cross-sectoral linkages}

To summarize, the banking and insurance businesses are still very different, but they have become more interlinked and the traditional sectoral borders have become more blurred. Authorities must duly recognize this evolution. If not, important sources of risk and vulnerability might be overlooked or a potential for competitive distortion might be created. This has been recognized by the relevant public authorities.

\footnotetext{
${ }^{3}$ FitchRatings (2003).

${ }^{4}$ OECD (2004); Standard and Poor's (2004).

5 The Joint Forum was established in 1996 under the aegis of the Basel Committee on Banking Supervision (Basel Committee), the International Organisation of Securities Commissions (IOSCO) and the International Association of Insurance Supervisors (IAIS). It investigates matters of common interest to the three financial sectors, in particular in the area of financial conglomerates.
} 
In the regulatory field, this was acknowledged foremost with the adoption of the Financial Conglomerates Directive, ${ }^{6}$ which the Member States had to implement in national law by August 2004. This Directive has put into place the broad regulatory framework for financial conglomerates, which the ECB very much supports. It addresses the issue of capital adequacy, in particular the avoidance of multiple gearing, establishes the monitoring of intra-group transactions and ensures adequate cooperation among the competent authorities. From a central banking perspective, an important element is the smooth flow of information from the supervisory authorities to the central banks, which the latter need in order to perform their tasks. In crisis situations, timely communication and coordination with central banks is paramount. In this respect, the Directive provides for a possibility for such an exchange.

In the supervisory field, banking and insurance supervisors have reacted to the growing cross-sectoral linkages by setting up between them mechanisms for information exchange and coordination. These can take a variety of forms. For example, a Memorandum of Understanding contains the general principles on which the cooperation between independent authorities has been set up. A much bolder solution would be the establishment of a unified supervisor, a model which some EU Member States have adopted in the recent past. Efficient intermediate solutions are also possible, such as the setting-up of joint councils of banking and insurance supervisors or mutual board representations.

Finally, in the area of financial stability monitoring by central banks, an approach that is too sector-orientated should be avoided, duly recognizing the different interlinkages between the financial system's different constituent parts. In that respect, the wide scope of the financial stability work that is presently being undertaken at the ECB in collaboration with the BSC should be recalled.

\section{Some major challenges ahead for the insurance sector}

This brief overview of the insurance sector from a financial stability point of view can be concluded by mentioning the major challenges that the sector will face in the near term. First, it is essential that insurers' risk management capabilities keep pace with their risk profile. In the expectation of boosting investment returns, some insurance companies have in past years taken on more risk through the equity market and the market for CRT instruments. This strategy led to balance sheet mismatches and did not always deliver the expected outcome. As financial risks continue to exist despite a considerable easing of pressures, it cannot be excluded that some insurance companies may again be tempted to move into risky asset classes without necessarily having the risk management skills this requires.

A second and somewhat related challenge is the European Commission's Solvency II project. Just like the banking sector's Basel II project, this initiative aims to reform capital requirements for insurers by introducing a three-pillar structure. Since the new

\footnotetext{
${ }^{6}$ Directive 2002/87/EC of 16 December 2002.
} 
regime aims at a better match between the true risk profile of an insurance company and its solvency requirements, it will ultimately contribute positively to financial stability.

The third challenge is the forthcoming introduction of the International Accounting Standards (IAS). In this respect, the insurance sector has expressed concerns that the new rules concerning fair value accounting evaluations could increase short-term volatility in financial statements, which seems to be at odds with the businesses' longterm nature.

And, finally, a last challenge, which again also applies to the banking sector, is ensuring the efficient functioning of the new institutional infrastructure recently set up for the EU financial sectors following the recommendations of the "Lamfalussy Committee". The purpose of this new arrangement is to increase the speed and efficiency of the European regulatory and supervisory system in order for it to remain effective and to reduce the burden caused by national regulatory and supervisory differences.

\section{References}

ECB (2004) Credit RiskTransfer by EU Banks: Activities, Risks and Risk Management (May).

FitchRatings (2003) Global Credit Derivatives: A Qualified Success (September).

OECD (2004) 'The performance of financial groups in the recent difficult environment', Financial Market Trends (March): 63-81.

Padoa-Schioppa, T. (2003) 'Central banks and financial stability: Exploring a land in between', in V. Gaspar, P. Hartmann and O. Sleijpen (eds) The Transformation of the European Financial System Second ECB Central Banking Conference (May).

Standard \& Poor's (2004) European Bancassurance: Is There Still Life in the Model? (February).

\section{About the author}

Jean-Claude Trichet is Governor of the European Central Bank and Chairman of the Group of Ten Governors. In 1993, he was appointed Governor of the Banque de France. He was chairman of the Monetary Policy Council of the Banque de France, member of the Board of the European Monetary Institute from 1994 to 1998 and has been member of the Governing Council of the European Central Bank since 1998. He was appointed to a second term as governor of the Banque de France in 1999. He is a graduate of the Institut d'Etudes Politiques de Paris and holds a Master's in economics. 